Rafał Kopeć* $^{*}$

\title{
The Determinants of the Israeli Strategic Culture
}

KEYWORDS: strategic culture, security threats, qualitative edge

SŁoWA KLUczowe: kultura strategiczna, zagrożenia dla bezpieczeństwa, supremacja jakościowa

\section{The notion of strategic culture}

The concept of strategic culture is the result of the need to take into account the factors that classical interpretation - based on a realistic paradigm - used to skip in international relations. Realists who referred to theoretical models, like the model of rational choice and game theory, assumed that the logic directing the activities of the states in each case is similar and it comes down to maximize the national interest in the anarchic environment. Thus they neglected cultural factors (values, ideas, beliefs, ideas), somehow perceiving international relations through material factors.

A research program of constructivists has played an important role in filling this gap, which was based on the assumption that the social world (including the international reality), is the collective creation of social awareness ${ }^{1}$ and social facts are not fixed forever but are socially, culturally and historically constructed ${ }^{2}$.

* Ph.D. in Political Science, Institute of Security and Civil Education, Pedagogical University in Krakow. Mail: r.kopec@up.Krakow.pl.

1 R. Wiśniewski, Kultura strategiczna, czyli o kulturowych uwarunkowania polityki zagranicznej i bezpieczeństwa, „Przegląd Strategiczny”, 2012, No. 1, p. 163.

2 Ł. Kamieński, Farmakologizacja wojny: historia narkotyków na polu bitwy, Kraków 2012, p. 21. 
Cultural interpretations of foreign and security policy - represented by such authors as Peter J. Katzenstein ${ }^{3}$, Jeffrey W. Legro ${ }^{4}$, Alexander Wendt ${ }^{5}$ or Alastair Iain Johnston ${ }^{6}$ focus on the existence of intersubjective structures (e.g. standards, ideas, identity) that give importance to the material world, they influence the behavior of participants in international relations. These structures combine to form the dominant narratives (culturally cohesive communities tend to adopt some of the narratives and reject the alternative ones ${ }^{7}$ ), acting as lens through which communities look at the events, which to some extent directs reactions to them ${ }^{8}$. Strategic culture must form a context within which entities - particularly the political and military elites - examine the issue.

The approach in the spirit of strategic culture does not stand completely opposed to rationality. In fact, however, this research program is compatible with the assumption of bounded rationality (strategic culture as a mechanism for simplification of reality), processed rationality (frames of strategic culture can establish a hierarchy of preferences or narrow options) or adapting rationality (factors such as historical experience, analogies, metaphors and precedents can serve as signposts indicating the choices) ${ }^{9}$. So strategic culture is an intangible environment (the concept of space), which narrows our choices in the sphere of behavior. In short: if the elites (which, although they are „stewards” of strategic culture and can to some extent shape it, they also remain under its influence) would be embedded in the same conditions, but previously were socialized in different strategic cultures, may take decisions that are different from each other. According to Alastair Iain Johnston, strategic culture is „system of symbols (e.g., argumentation structures, languages, analogies, metaphors) which acts to establish pervasive and longlasting strategic preferences by formulating concepts of the role and efficacy of military force in interstate political affairs, and by clothing these conceptions with such an aura of factuality that the strategic preferences seem uniquely realistic and efficacious" 10 .

3 The Culture of National Security: Norms and Identity in World Politics, P.J. Katzenstein (edit), New York 1996.

4 J.W. Legro, Culture and Preferences in the International Cooperation Two-Step, [in:] „American Political Science Review", 1996, Vol. 90, No. 1, pp. 118-137.

5 A. Wendt, Anarchy is What States Make of It: The Social Construction of Power Politics, „International Organization”, 1992, Vol. 46, No. 2, pp. 391-425.

6 A. I. Johnston, Thinking about Strategic Culture, „International Security”, 1995, Vol. 19, No. 4, pp. 32-64.

7 J. S. Duffield, World Power Forsaken: Political Culture, International Institutions, and German Security Policy After Unification, Stanford 1999, p. 2.

8 J.S. Lantis, Strategic Culture and Tailored Deterrence: Bridging the Gap between Theory and Practice, „Contemporary Security Policy”, 2009, Vol. 30, No. 3, p. 472.

9 A. I. Johnston, op. cit., p. 34.

10 Ibidem, p. 46. 
Strategic culture is not synonymous with the military culture. The latter, as a kind of culture of organization, is more consistent (although you can distinguish between the cultures of different kinds of armed forces). It is characterized by having an internal social architecture, which the strategic culture lacks ${ }^{11}$. The concept of strategic culture to a greater extent, in turn, is embedded in a broader context - political, social, historical or geographical. It is also less homogeneous. The given strategic culture is often internally diverse, dividing into separate subcultures (Jack L. Snyder in his pioneering work in 1977 distinguished subcultures within the Soviet strategic culture ${ }^{12}$ ).

Rafał Wisniewski, on the bases of the works of Colin S. Gray, Thomas G. Mahnken and Krzysztof Malinowski, carries embedding the concept of strategic culture within a hierarchical set of culture relating to foreign policy and security ${ }^{13}$. At the highest level, we should place the political culture that includes elements of culture pertaining to the sphere of politics. Within its framework the culture of national security functions, shaping beliefs concerning the sphere of security policy, including the political aspects of the use of military force. One of its components is the strategic culture, deciding on issues related to the use of military instruments in external relations. Within its framework the organizational culture of the armed forces exists, which is often equated with „national way of waging war”, which in turn consists of organizational cultures of different types of troops.

\section{Geopolitical background of Israel}

Israel's strategic culture is largely determined by geopolitics. A glance at the map of the Middle East gives an idea of the isolation of this country, surrounded by the states, if not hostile, at least unfavorable. In conjunction with the perception of the security environment in the spirit of realism as a dangerous and unpredictable one, it has shaped a siege mentality ${ }^{14}$. The view at the issues of the international environment is in the spirit of Hobbes, based on the principle that each of its participants may rely primarily, or even exclusively, on himself. This involves trusting in the „tough” strength. So the army is a central institution of the state and society, to the extent that it has led to the production of informal civil-military network dominating the sphere of national

11 J.H. Miller, Strategic Culture as the Basis for Military Adaptive Capacity: Overcoming Battlefield Technological Surprises, University of Pennsylvania, p. 24, http://repository.upenn.edu/ curej/173/, 20.04.2015.

12 J.L. Snyder, The Soviet Strategic Culture: Implications for Limited Nuclear Operations, Santa Monica 1977, pp. 10-12.

13 J. Wiśniewski, op. cit., pp. 172-173.

14 B. Berti, Seeking stability: Israel's approach to Middle East and North Africa - Analysis, EurAsia Review, p. 1, http://www.eurasiareview.com/19032015-seeking-stability-israels-approach-tomiddle-east-and-north-africa-analysis/, 23.05.2015. 
security, but also gaining the key position in many other areas of public life ${ }^{15}$. People attach much less importance to the elements of soft power, for example, diplomacy, so that the possibilities of exerting political influence in the region are limited.

"The siege mentality" is in a special way connected with the "ghetto mentality", resulting from the experience of two thousand years of living in the Diaspora ${ }^{16}$. This creates a kind of strategic fatalism manifesting itself in preparing for the worst case scenario and an attitude of „not budge an inch”.

This attitude is understandable when we consider another geopolitical factor, which is a small territory of the country, especially in comparison with the size of the territories of hostile neighboring countries. This results in a very limited strategic depth. In the event of war, the Israeli army has virtually no possibility of withdrawal in anticipation of the changing situation on the front. Figuratively speaking, Israel is not able to change the space into time ${ }^{17}$. Therefore, Israelis approach to security can not be strictly defensive.

Israel's defense policy is therefore defensive at the strategic level, based on deterrence and conducted in terms of the preservation of the status quo. At the operational and tactical levels, this translates into action, however, typically offensive ${ }^{18}$. One of the primary objectives is to prevent the intrusion of enemy forces on their own territory and to transfer fighting into enemy territory. This allows them to create a kind of artificial strategic depth ${ }^{19}$.

The aim is to prevent the escalation of the conflict and end the war with a positive result as soon as possible. During the Cold War, another factor that had to be taken into account was the pressure of great powers, which could result in forcing Israel to end the war before reaching the strategic objectives. Currently, the pressure of public opinion, both national and international plays a similar role, which negatively reacts to the protracted conflicts, and especially inevitable, in such cases, the losses of the army and among the civilian population (for example the decision to end the Second Lebanon War in 2006, despite the failure to achieve its goals, was largely due to public pressure $)^{20}$. These factors tend to favor the fast, almost instant wars ${ }^{21}$.

15 O. Barak, G. Sheffer, A Study of Civil-Military Relations in Israel: A New Perspective, „Israel Studies", 2007, Vol. 12, No. 1, pp. 17-18.

16 D. Adamsky, The Culture of Military Innovation: The Impact of Cultural Factors on the Revolution in Military Affairs in Russia, the US, and Israel, Stanford 2010, p. 115.

17 J.H. Miller, op. cit., p. 36.

18 Z. Maoz, Defending the Holy Land. A Critical Analysis of Israeli Security and Foreign Policy, Ann Arbor 2009, p. 13.

19 J.H. Miller, op. cit., p. 36.

20 K. Kubiak, Hybrydowa wojna w Libanie, „Raport - Wojsko Technika Obronność”, 2006, No. 10, pp. 72-81.

21 E. Cohen, M. Eisenstadt, A. Bacevich. "Knives, Tanks, and Missiles": Israel's Security Revolution, Washington 1998, p. 17. 
In this case, the foundations of the approach to national security are strategic deterrence, early warning and the desire to get a quick settlement on the battlefield. Deterrence, both nuclear and conventional, is to prevent conflict which, if lost would mean the annihilation of Israel (in contrast to the Arab countries that could afford to fail). The fear of annihilation also explains the uncompromising attitude towards military nuclear programs of its neighbors. Israel is in fact the so-called one-bomb-statea state that can be destroyed by a single nuclear attack ${ }^{22}$.

The second pillar, that is early warning, is to give time for calling up the reserves. The purpose of the relatively small regular army is primarily to withstand the pressure of the first phase of the enemy attack. The third pillar, the desire for rapid military settlement, in addition to the previously mentioned factors, is also determined by having relatively small human resources, which excludes the conduct of the war of attrition. This dictated the pursuit of an aggressive maneuver war, based on a combination of armored forces and close support of aircraft. It was perceived as the only available form of war for Israel. Certainly, the intellectual inspiration was the German blitzkrieg, despite the peculiar irony of the situation. Although the "Israeli blitzkrieg” never manifested itself in the form of official doctrine, the military officials of this country certainly analyzed in detail the military actions of the Third Reich, as evidenced by the publication of numerous studies on the subject ${ }^{23}$. This proves their pragmatism, manifested in the choice of only using the criterion of effectiveness, excluding the "normative” agent, which obvious negative connotations of history were in this case.

The threat of full-scale aggression since making peace with Egypt at Camp David in 1979, has become relatively distant. Currently, the essential hazards of Israel's safety relate to two areas - below the threshold of a conventional large-scale aggression or above this threshold ${ }^{24}$. The first one is the so-called sub-conventional threats - terrorism and regional conflicts of low intensity (activities are carried out by non-state actors, but supported by the states). In turn, the over-conventional risks are associated with implementing programs of development of weapons of mass destruction (particularly nuclear weapons) and their means of delivery by the states of the Middle East.

Such a perception of threat interacts with the three circles of defense distinguished by the Israeli security policy. The first relates to the within-border risks, the second to the peripheral, while the third to the distant ones ${ }^{25}$. The within-border threats mani-

22 G.F. Giles, Continuity and Change in Israel's Strategic Culture, Defense Threat Reduction Agency, p. 25, http://fas.org/irp/agency/dod/dtra/israel.pdf, 20.05.2015..

23 D. Adamsky, op. cit., p. 112.

24 M. Raska, Beyond the 'Bomb in the Basement': Israel's Nuclear Predicament and Policy Options, „Asian Journal of Public Affairs”, 2007, Vol. 1, No 2, p. 24.

25 M. Raska, Creating Reverse Asymmetry: Israel's Military Innovation, Royal United Service Institute, https://www.rusi.org/publications/newsbrief/ref:A50F816CB514B2/\#.VWtprmf77cs, 24.05.2015. 
fest themselves within the state, and terrorist attacks are their dominant form (the sub-conventional risks). Peripheral threats are the threats to the territorial integrity of Israel of a handful scale conventional attack from neighboring countries. Finally, the distant threats refer to the states in some distance from Israel, but having the means of projecting power of required range. In this case, it means primarily the weapons of mass destruction in conjunction with the means of its delivery (so they are over-conventional threats).

As part of Israel's strategic culture, we can distinguish some different approaches, but they all have to recognize that the threat to Israel is also a threat to the Jewish community, and the military sphere is central to ensure thier survival. These subcultures within the strategic culture can be distinguished on the basis of the dominant orientation, indicating (following the Baruch Kimmerling) into three mainstreams ${ }^{26}$ :

- the security orientation. This is the most „mainstream”, but also the most diverse orientation. It sees Israel as entwined in the grip of war with its Arab neighbors, where the stake is the survival or annihilation. The basic assumption is the need to maintain absolute military superiority in the region. The most important duty of every member of the Israeli society is military service, and the state has the unquestionable right to define its character. However, the state should not abuse the tendency of citizens to self-sacrifice, but use military force only for the purpose of survival.

- the conflict orientation. It assumes that the Arab-Israeli conflict is the next incarnation of the historical anti-Semitism. In the current geopolitical situation, as well as in the foreseeable future, there is no possible peace agreement. In the spirit of realism, a military power is considered as the most important factor affecting relations between states, nations and religious groups. Repeated cycles of war are therefore inevitable and absolutely must end in victory for Israel, and all other group or individual goals must be subordinated to this goal. This orientation emphasizes the relationship with the land of Israel (including the moral and religious ones), and assumes that they must possess and maintain as many territories as possible (the faction of this orientation are settlers in the West Bank);

- the peace orientation. It is the antithesis of the conflict orientation. The IsraeliArab conflict is not seen in the context of previous persecution of the Jews, but in terms of interests, e.g. of the lands, water or markets. As such, it may therefore be subject to negotiations and achieving peace will require compromises (e.g. the formula of „land for peace”). Peace, along with the recognition of Israel as being legitimized by neighboring countries, is considered the best guarantee of security and

26 B. Kimmerling, The Invention and Decline of Israeliness: State, Society, and Military, Berkley 2001, pp. 208-228. 
development. The relationship between the state and society are mutual. The state is to ensure the safety, welfare and rights of man and the citizen is to obey the law, pay taxes and serve in the military, if necessary. This orientation is quite popular among journalists (including daily Haaretz) and artists as well as among Ashkenazi lower middle class (in this trend there is eg. the program of Meretz party).

\section{The social characteristic of Israel}

Social conditions of the Israeli strategic culture are partly rooted in the distant past, in part, on the other hand refer to the recent history of Israeli society. The system of symbols shaping this culture partly extends until the times of the Bible. One of these key symbols is the image of the Jewish people as a source of persecution. This picture does not refer only to the Holocaust or the nineteenth-century pogroms against Jews in Eastern Europe, but also to Egyptian slavery, the Babylonian and Roman rule.

Certain myths of ancient origins have been specifically cultivated to this day. An example is the myth of Masada, which is a part of the indoctrination of soldiers of the Israel Defense Forces (IDF, Hebrew CaHaL) ${ }^{27}$. It should be noted that the IDF, based on common military service, are a tool to penetrate the society with ideas typical of Israeli strategic culture (mainly insecurity and conviction of the necessity of sacrifice in the name of safety $)^{28}$. These ideas are shared, therefore, not only by the military or political elites, but they are quite commonly represented by the whole society.

The biblical distinction between two categories of war is also typical Israeli strategic culture. One of them is a necessary war, imposed by others (e.g. The Yom Kippur War in 1973), thus perceived as fair and is the subject of the within-society consensus. The second category is a war of choice, optional, so controversial and morally ambiguous (e.g. the war in Lebanon in 1982 or the so-called Second Lebanon War in 2006) ${ }^{29}$. In the Bible, you can also detect the sources of the principle „an eye for an eye," which became the basis for a decision about the operation „Wrath of God”, assuming liquidation of the members of the organization Black September, who attacked the Israeli athletes at the Olympic Games in Munich in $1972^{30}$.

Referring to the contemporary social conditions affecting Israeli strategic culture, it is difficult to ignore the characteristics of such a particular being as the Israeli society. It must be emphasized that it is a kind of hybrid of individualism and collectivism

27 G.F. Giles, op. cit., p. 3.

28 Ibidem, p. 4.

29 Ch. Ben-Dor, War \& Peace: Jewish Tradition and the Conduct of War, „Israeli Defense Forces Journal", 1986, Vol. 3, No. 4, pp. 47-50.

30 G.F. Giles, op. cit., pp. 19-20. 
(with the provision that there is a process of gradual moving away from collectivist attitudes $)^{31}$. A particularly important feature of individualism is the belief of the need to rely on themselves, while collectivism involves tying attention to the common good and the pursuit of collective goals. Both of these attitudes are highly visible in the Israeli society.

Zionism sought to forge a „new Jew” (sabra), who was to be the antithesis of a Jew of Diaspora - timid, fearful of authority, characterized by the victim mentality, avoiding to take their fate in their own hands ${ }^{32}$. The new Jew was to be strong internally and without complexes, without fear of building their lives and their communities on the ground, which they considered their own. The spirit of initiative is reflected even in the way of commanding typical for IDF. It consists in issuing general directives and leaving subordinates with wide room for maneuver, so that they in their reasonable discretion could transform the spirit of orders into specific actions ${ }^{33}$. Own initiative, innovation, new ideas - these are desirable elements in the armed forces, while their absence is badly received. Israel has never freed itself from what Martin van Crevald describes as „organized chaos” (i.e. free interpretation of the purpose of the operation) ${ }^{34}$.

A relatively egalitarian atmosphere of Israeli society, created in its beginnings, also favored such an approach. To some extent, it had to penetrate even such a hierarchical structure, which the army is. This results in a relatively flat structure, a relatively small military bureaucracy and open channels of communication through which innovative ideas can quickly find their way „up”. It harmonizes with the specific style of communication of „new Israelis” (born in Israel) - dugri: simple, authentic, and sincere, where the content is more than form, leaving no field to interpret, sometimes even confrontational. In this context, the "diplomatic" style is treated as artificial and hypocritical. Communication in tachlis style ("straight to the point") became a part of the cultural socialization of immigrants from different parts of the world ${ }^{35}$.

Israeli mentality is the mentality of people working, not discussing, not „philosophers", but practitioners. This is reflected in the social structure of Israel, which intentionally was to be reversed in relation to the social structure of the Diaspora. It assumes the existence of a large and productive working class, with a small minority of intelligentsia (both religious and secular). Theoretical knowledge is equated with weakness and a lack of productivity, and the central character of a new Israeli society was no longer the sage (rabbi), but the farmer ${ }^{36}$. A social icon has become a „man of the plow

31 D. Adamsky, op. cit., p. 110.

32 Ibidem.

33 Ibidem, p. 118.

34 M. van Crevald, The Sword and the Olive, New York 2002, p. 161.

35 D. Adamsky, op. cit., p. 110.

36 Ibidem, p. 119. 
and rifle," hard working on their land and ready to defend it, nonconformist, not fearing of difficulties and not shunning risk, defiant in a positive sense, colloquially speaking, „the guy with the guts” (culture of the new Israeli society has even a macho trait) ${ }^{37}$.

This translates into an approach to the military issues - practical, instrumental, action-oriented and problem-solving, often by improvisation. The project of Israeli armed forces and their location within the overall social organism assumed the emergence of non-professional army, linked by strong bonds with the society, but - due to the strong criticism of militarism - not dominating it in a way that would lead to the transformation of Israel into a garrison country in the Prussian style ${ }^{38}$.

Such linking of the army with the society-oriented pragmatism created a specific military culture, which can be called anti-intellectual. It focuses on solving specific problems rather than on a general approach. This results in a short-term focus, and is dominated by an ad hoc approach. The proof of this is the fact that the first operational doctrine called the Concept of Operations (CONOP) was not published until 2006, meeting anyway very ambiguous response. In the context of the IDF failures in the war in Lebanon, which took place a few months after the publication of the doctrine, CONOP was accused of excessive intellectualism and postmodern language that caused that the tactical level commanders had difficulty in translating it into specific actions ${ }^{39}$.

Meanwhile, Israelis military tradition glorifies flexibility and improvisation. In conditions of war, many military organizations generate a kind of „short cut”, but in very few cases, it becomes a widely functioning "procedure" to the extent as it is in Israel. Exceptionally frequent fighting experiences are favorable to it, while minimizing the number of routine habits of the garrison life or distortions in the way of acting acquired during detached from the realities of the actual battlefield exercises in peacetime ${ }^{40}$.

They value therefore the officers for the ability to quick orientating themselves in a situation, to independent thinking in the face of uncertainty, to trust their own judgment and capture the initiative in all conditions ${ }^{41}$. This spirit of improvisation manifested itself even in the Yom Kippur War, when the Arab states surprised Israel with the use of antiaircraft rocket systems and antitank guided missiles. The first ones challenged the dominance of the Israeli Air Force in the air, the latter meant that it became impossible to repeat the success of the campaign of 1967, assuming a rapid offensive of armored troops. The Israeli army was forced to make a quick, only in a few days, crea-

37 H. Herzog, Homefront and Battlefront, [in:] Israeli Women's Studies: A Reader, E. Fuchs (edit.), Piscataway 2005, p. 214.

38 D. Adamsky, op. cit., p. 122.

39 Ibidem, p. 118.

40 G.F. Giles, op. cit., p. 37.

41 D. Adamsky, op. cit., p. 117. 
tive adaptation to the changing battlefield ${ }^{42}$. In this case, the Israeli military culture demonstrated the ability to deal with the inevitable war "surprises” on the part of the enemy $^{43}$. It should be noted that they lacked the ability to run the campaign in such a way in 2006 and the war ended with the strategic stalemate and with the overwhelming defeat of the IDF in the symbolic sphere.

The price for such an attitude is "tacticization of strategy" - the replacement of strategy with improvised thinking dictated by tactical determinants. Detailed planning is at the tactical level and in the field of technology, while at the strategic level there is a kind of amateurishness, resulting from the lack of emphasis on strategic planning ${ }^{44}$. Informal and a much-institutionalized way of working out decisions („in the shade of offices") crystallized during the war of independence, when the security environment was so unpredictable that the key was improvisation. Currently, this feature of reluctance to strategic planning in the long term can be observed in relation to the conflict with the Palestinians, where the tendency to "manage" it, and not to solve it, dominates ${ }^{45}$, or in a minimalist policy towards the events in the aftermath of the so-called Arab Spring. Although the reconstruction of the Middle East security architecture is of fundamental importance for the security of Israel, the country avoids speaking out on either side and instead focuses on the challenges in the short-term perspective.

At the tactical level, the essential aim is the unquestioned supremacy of quality (qualitative edge). The possession of weapons more advanced technologically and the ability to use it in a more professional way were to overcome the outnumbering enemy. The quality therefore was to apply not only to the material factors, but also to the human ones. In the early years of Israel's existence, they had significant problems with the acquisition of modern weaponry abroad and its own defense industry was not yet sufficiently developed. The supremacy of quality necessarily referred mainly to "human material". Gradually, however, the importance of the technology was increasing, and the role of the human factor went down to the second place. Especially after 1973, there was a narrowing of perception of qualitative edge primarily to technological issues, while neglecting intangible factors and the gradual disappearance of military thinking $^{46}$. Israel was the first country after the United States, which commonly used a precision weapon. The technique became a panacea for the problems of security; it even started to dictate strategy. This led to the formation of a special continuum: the solution to the issue of security has become the use of military force, and a technological

42 J.H. Miller, op. cit., pp. 47-54.

43 M. Finkel, On Flexibility: Recovery from Technological and Doctrinal Surprise on the Battlefield, Stanford 2001, pp. 164-178.

44 D. Adamsky, op. cit., p. 116.

45 B. Berti, op. cit., p. 7.

46 D. Adamsky, op. cit., p. 115. 
advantage has become the military solution to the issue. This relationship is perfectly illustrated by the solution to the problem of firing the territories of Israel with the help of improvised rockets launched en masse from the territory of the Gaza Strip. The solution to this was Iron Dome, an air defense missile system.

\section{Conclusions}

The realistic orientation, observing the activities of the states in the sphere of the foreign and security policy through material factors (national interest), needs to be complemented by the view of taking into account cultural factors. A constructivist research program offers such optics. Its element is the concept of strategic culture.

Considering the shape of the strategic culture of Israel, we should take into account both the geopolitical factors, and the nature of Israeli society. We include into the key elements of strategic culture, formed under the influence of geopolitical factors, the "siege mentality" and the desire to get a quick military settlement, preferably by transferring the conflict into the territory of the enemy. This desire comes from the very limited strategic depth of Israel. These elements have shaped typical for Israel dualism in approach to security policy - thinking in defensive terms dominates at the strategic level (this "besieged fortress"), at the lower levels (tactical and operational) it translates, however, into the actions of offensive character, precisely in order not to allow the enemy to the penetrate their territory.

Social factors also explain the specificity of the Israeli approach. The culture of improvisation and initiative, typical for the Israeli military sphere, and the cult of practical actions are reflected in the nature of the "new Israeli society". The tendency to increase the role of the technological factor, which we can also see in the recent years, stems from the socio-economic conditions of Israel.

The approach in terms of strategic culture may therefore be a useful tool for anal-

ysis and, to a limited extent, even the prediction of the state's activities in the field of foreign and security policy.

\section{Bibliography}

Adamsky D., The Culture of Military Innovation: The Impact of Cultural Factors on the Revolution in Military Affairs in Russia, the US, and Israel, Stanford 2010.

Ben-Dor Ch., War \& Peace: Jewish Tradition and the Conduct of War, „Israeli Defense Forces Journal", 1986, Vol. 3, No. 4.

Cohen E., Eisenstadt M., Bacevich A., "Knives, Tanks, and Missiles": Israel's Security Revolution, Washington 1998.

Crevald van M., The Sword and the Olive, New York 2002. 
Duffield J. S., World Power Forsaken: Political Culture, International Institutions, and German Security Policy After Unification, Stanford 1999, p. 2.

Finkel M., On Flexibility: Recovery from Technological and Doctrinal Surprise on the Battlefield, Stanford 2001.

Giles G.F., Continuity and Change in Israel's Strategic Culture, Defense Threat Reduction Agency, http://fas.org/irp/agency/dod/dtra/israel.pdf, [access: 20.05.2015].

Herzog H., Homefront and Battlefront, [in:] Israeli Women's Studies: A Reader, E. Fuchs (edit.), Piscataway 2005.

Johnston A. I., Thinking about Strategic Culture, „International Security”, 1995, Vol. 19, No. 4.

Kamieński Ł., Farmakologizacja wojny: historia narkotyków na polu bitwy, Kraków 2012.

Kimmerling B., The Invention and Decline of Israeliness: State, Society, and Military, Berkley 2001.

Kubiak K., Hybrydowa wojna w Libanie, „Raport - Wojsko Technika Obronność”, 2006, No. 10.

Lantis J.S., Strategic Culture and Tailored Deterrence: Bridging the Gap between Theory and Practice, „Contemporary Security Policy”, 2009, Vol. 30, No. 3.

Legro J.W., Culture and Preferences in the International Cooperation Two-Step, „American Political Science Review", 1996, Vol. 90, No. 1.

Maoz Z., Defending the Holy Land. A Critical Analysis of Israeli Security and Foreign Policy, Ann Arbor 2009.

Miller J.H., Strategic Culture as the Basis for Military Adaptive Capacity: Overcoming Battlefield Technological Surprises, University of Pennsylvania, http://repository.upenn.edu/curej/173/, [access: 20.04.2015].

Raska M., Beyond the 'Bomb in the Basement': Israel's Nuclear Predicament and Policy Options, „Asian Journal of Public Affairs”, 2007, Vol. 1, No 2.

Raska M., Creating Reverse Asymmetry: Israel's Military Innovation, Royal United Service Institute, https:// www.rusi.org/publications/newsbrief/ref:A50F816CB514B2/\#.VWtprmf77cs, [access: 24.05.2015].

The Culture of National Security: Norms and Identity in World Politics, Katzenstein P.J. (edit.), New York 1996.

Wendt A., Anarchy is What States Make of It: The Social Construction of Power Politics, „International Organization", 1992, Vol. 46, No. 2.

Wiśniewski R., Kultura strategiczna, czyli o kulturowych uwarunkowania polityki zagranicznej i bezpieczeństwa, „Przegląd Strategiczny”, 2012, No. 1.

\section{The Determinants of the Israeli Strategic Culture}

ABSTRACT

The notion of strategic culture concentrates on intangible aspects that shape foreign and security policies of every state. The article presents the determinants of Israeli strategic culture considering both Israeli geopolitical situation, and the factors modeling its social landscape.

\section{Determinanty izraelskiej kultury strategicznej}

STRESZCZENIE

Pojęcie kultury strategicznej koncentruje się na pozamaterialnych czynnikach kształtujących funkcjonowanie państw w sferze polityki zagranicznej i bezpieczeństwa. Artykuł prezentuje determinanty izraelskiej kultury strategicznej, poszukując ich zarówno w uwarunkowaniach geopolitycznych Izraela, jak i w czynnikach kształtujących społeczny krajobraz tego państwa. 